\title{
PENGARUH GAYA KEPEMIMPINAN, MOTIVASI DAN DISIPLIN KERJA TERHADAP KINERJA PENDIDIK YAYASAN MARVIN
}

\author{
Denok Sunarsi ${ }^{*}$ \\ Email : denoksunarsi@gmail.com
}

\begin{abstract}
ABSTRAK
Penelitian ini bertujuan untuk menguji dan menganalisis pengaruh gaya kepemimpinan, motivasi dan disiplin kerja terhadap kinerja pendidik Yayasan Marvin. Pengumpulan data dilakukan melalui penyebaran kuesioner dan dilaksanakan pada 112 karyawan Yayasan Marvin. Analisis data pada penelitian ini menggunakan bantuan SPSS versi 17. Teknik sampling yang dipakai adalah metode sensus dan teknik pengujian data yang digunakan dalam penelitian ini meliputi uji validitas dengan analisis faktor, uji reliabilitas dengan Alpha Cronbach. Uji asumsi klasik dan analisis regresi liner berganda, untuk menguji dan membuktikan hipotesis penelitian. Hasil analisis menunjukkan bahwa gaya kepemimpinan berpengaruh positif terhadap kinerja pendidik. Motivasi berpengaruh positif terhadap kinerja pendidik dan disiplin kerja berpengaruh positif terhadap kinerja pendidik.

Kata Kunci: Gaya kepemimpinan, Motivasi, Disiplin Kerja dan Kinerja Pendidik.
\end{abstract}

\section{ABSTRACT}

The research aims to examine and analyze the influence of leadership style, motivation and work discipline toward performance of pedagogue in Yayasan Marvin. Data collected through distribution of questionnaires and it is implemented Yayasan Marvin's 112 employee. Analysis of data in this research using the help of SPSS version 17. A sampling technique uses a census method and data test technique is used within the research includes validity test by factor analysis, reliability test with cronbach. Classic assumption test and double linear regression analysis, to verify and to prove the research hypothesis. Analysis result demonstrates that leadership style have a positive influence toward pedagogue performance. Motivation have a positive influence toward pedagogue performance and work discipline have a positive influence toward pedagogue performance.

Keywords: Leadership style, Motivation, Work discipline and Pedagogue performance.

*) Dosen Program Studi Manajemen S-1, FE-UNPAM

\section{PENDAHULUAN}

\section{A. Latar Belakang}

Indonesia adalah negara dengan jumlah penduduk yang sangat padat, kira-kira terdapat 232,516.8 juta jiwa lebih penduduk di Indonesia, dengan jumlah penduduk yang sangat besar, Indonesia memliki potensi SDM yang sangat besar dari segi kuantitas, lalu bagaimana kualitas SDM indonesia di mata dunia. Menurut data dari Human Development Indeks, Indonesia berada pada peringkat 108 di dunia dari segi Kualitas SDM. Dunia pendidikan sekarang ini secara nyata telah berkembang pesat, 
dengan didukung oleh teknologi, dunia pendidikan dimungkinkan dapat mempersiapkan sumber daya manusia yang mampu bersaing di dalam era globalisasi. Seiring dengan perkembangan pendidikan di Indonesia dengan diberlakukannya Undang Undang Nomor 22 Tahun 1999 tentang Pelaksanaan Pemerintah Daerah membawa konsekuensi logis pada perubahan paradigma pengelolaan pendidikan dari yang bersifat sentralistis menjadi desentralitis.

Perubahan ini, pada satu sisi munguntungkan sebab pendidikan di sekolah dapat dilaksanakan secara lebih leluasa dan mandiri sesuai dengan kemampuan masingmasing sekolah, namun pada sisi lain akan menjadi kendala pada pelaksanaannya apabila kesiapan sekolah tidak sejalan dengan tuntutan dari kebijakan undang undang tersebut. Salah satu upaya pemerintah untuk mendukung pelaksanaan undang undang tersebut adalah dengan meningkatkan kualifikasi pendidikan guru melalui program penyetaraan. Guru-guru Sekolah Dasar (SD), minimal harus berlatar belakang (DII), guru-guru SLTP minimal harus berlatar belakang (DIII), sedangkan guru-guru SLTA minimal harus berlatar belakang (S1). Dalam pelaksanaannya menuntut perubahan sikap dan tingkah laku dari seluruh komponen sekolah, baik kepala sekolah, guru dan staf administrasi, termasuk orangtua dan masyarakat dalam memandang, memahami dan membantu sekaligus sebagai pemantau yang melaksanakan monitoring dan evaluasi dalam pelaksanaan sekolah. Perubahan sikap dan tingkah laku tersebut akan dapat terjadi bila sumberdaya sekolah yang ada dimanfaatkan dan dikelola secara optimal dan efektif oleh kepala sekolah selaku orang yang bertanggung jawab dalam pelaksanaan pendidikan di sekolah.

Terdapat faktor negatif yang dapat menurunkan Kinerja Pendidik, diantaranya adalah menurunnya keinginan karyawan untuk mencapai prestasi kerja, kurangnya ketepatan waktu dalam penyelesaian pekerjaan sehingga kurang menaati peraturan, pengaruh yang berasal dari lingkungannya, teman sekerja yang juga menurun semangatnya dan tidak adanya contoh yang harus dijadikan acuan dalam pencapaian prestasi kerja yang baik. Semua itu merupakan sebab menurunya Kinerja Pendidik dalam bekerja. Faktor-faktor yang dapat digunakan untuk meningkatkan kinerja diantaranya adalah gaya kepemimpinan, Motivasi dan disiplin kerja.

Berdasarkan survei pendahuluan, peneliti menemukan adanya kekurangmenaati tata tertib, ketentuan-ketentuan perusahaan yang memberatkan karyawan, disamping gaya kepemimpinan dan Motivasi yang cukup tinggi. Kemudian timbul pemikiran bagaimana keseluruhan faktor tersebut saling berkesinambungan sehingga mempengaruhi Kinerja Pendidik. Mengingat pentingnya masalah tersebut, dan untuk menyikapi kondisi tersebut diatas, maka dilakukan penelitian yang berkaitan dengan "Pengaruh Gaya Kepemimpinan, Motivasi Dan Disiplin Kerja Terhadap Kinerja Pendidik di Yayasan Marvin".

\section{B. Perumusan Masalah}

Berdasarkan identifikasi masalah dan pembatasan masalah di atas maka penulis menetapkan perumusan masalah yaitu:

1. Seberapa besar pengaruh gaya kepemimpinan (X1) terhadap kinerja pendidik $(\mathrm{Y})$ ?.

2. Seberapa besar pengaruh Motivasi (X2) terhadap kinerja pendidik (Y)?.

3. Seberapa besar pengaruh disiplin (X3) terhadap kinerja pendidik (Y)?.

4. Seberapa besar pengaruh gaya kepemimpinan (X1), Motivasi (X2) dan disiplin (X3) terhadap kinerja pendidik $(\mathrm{Y})$ secara simultan?. 


\section{Paradigma Penelitian}

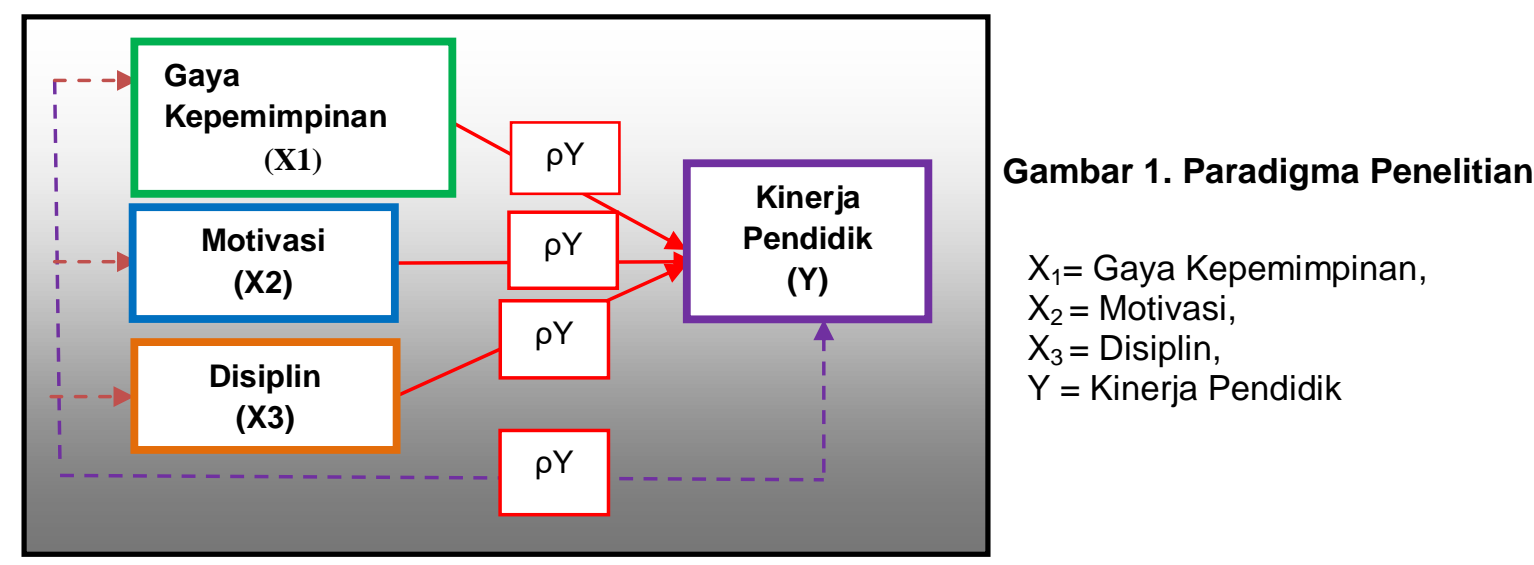

\section{TINJAUAN PUSTAKA DAN KERANGKA PEMIKIRAN}

\section{A. Gaya Kepemimpinan}

Kepemimpinan merupakan tulang punggung pengembangan organisasi karena tanpa kepemimpinan yang baik akan sulit mencapai tujuan organisasi. Jika seorang pemimpin berusaha untuk mempengaruhi perilaku orang lain, maka orang tersebut perlu memikirkan gaya kepemimpinannya. Gaya kepemimpinan adalah bagaimana seorang pemimpin melaksanakan fungsi kepemimpinannya dan bagaimana ia dilihat oleh mereka yang berusaha dipimpinnya atau mereka yang mungkin sedang mengamati dari luar (Robert, 1992:5).

Gaya kepemimpinan adalah perilaku dan strategi, sebagai hasil kombinasi dari falsafah, ketrampilan, sifat, sikap, yang sering diterapkan seorang pemimpin ketika ia mencoba mempengaruhi kinerja bawahannya (Tampubolon, 2007:9).

Berdasarkan definisi gaya kepemimpinan diatas dapat disimpulkan bahwa kepemimpinan adalah kemampuan seseorang dalam mengarahkan, mempengaruhi, mendorong dan mengendalikan orang lain atau bawahan untuk bisa melakukan sesuatu pekerjaan atas kesadarannya dan sukarela dalam mencapai suatu tujuan tertentu.

\section{B. Motivasi}

Motif dan Motivasi merupakan bagian dalam fungsi manajeman sumber daya manusia yaitu pengintegrasiaan. Menurut teori humanitis dalam (Hasibuan, 2005:14), perangsang yang paling dasar dari organisasi manusia tertuju pada perwujudan diri (self actualization), usaha keras yang terus menerus untuk mewujudkan potensi yang melekat pada dirinya. Orang yang melakukan perwujudan diri adalah orang yang berpusat pada persoalan (problem centered), demokratis, sangat kreatif, mampu mengadakan hubungan interpersonal yang mendalam, memuaskan, dan dapat segera menerima orang lain sebagaimana adanya.

Menurut (Hasibuan, 2005:141), Motivasi berasal dari kata Latin movere yang berarti dorongan atau menggerakkan. Motivasi dalam manajemen hanya ditujukan pada sumber daya manusia umumnya dan bawahan khususnya. Motivasi mempersoalkan bagaimana caranya mengarahkan daya dan potensi bawahan agar 
mau bekerja sama secara produktif berhasil mencapai dan mewujudkan tujuan yang ditentukan.

Berdasarkan beberapa pendapat para ahli tersebut dapat disimpulkan, bahwa Motivasi kerja adalah dorongan yang tumbuh dalam diri seseorang, baik yang berasal dari dalam dan luar dirinya untuk melakukan suatu pekerjaan dengan semangat tinggi menggunakan semua kemampuan dan ketrampilan yang dimilikinya. Motivasi merupakan respon pegawai terhadap sejumlah pernyataan mengenai keseluruhan usaha yang timbul dari dalam diri pegawai agar tumbuh dorongan untuk bekerja dan tujuan yang dikehendaki oleh pegawai tercapai.

\section{Disiplin Kerja}

Salah satu tantangan terberat yang sering harus dihadapi oleh seorang pimpinan atau top manajemen suatu perusahaan adalah bagaimana ia dapat menggerakkan para karyawan agar senantiasa mau dan bersedia mengerahkan kemampuan yang terbaiknya untuk kepentingan organisasi atau perusahaan. Salah satu usaha guna mengarahkan karyawan agar berperilaku sesuai dengan harapan ialah dengan melalui kedisiplinan kerja di perusahaan.

Menurut Handoko (2012:208) disiplin merupakan kegiatan manajemen untuk menjalankan standar-standar organisasional. Kegiatan yang dilaksanakan untuk mendorong para karyawan agar mengikuti berbagai standar dan aturan, sehingga penyelewengan-penyelewengan dapat dicegah.

Menurut P. Sagian (2008:130) menegaskan bahwa daya pendorong yang mengakibatkan seseorang anggota organisasi mau dan rela untuk mengerahkan kemampuan, peranan dalam bentuk keahlian dan keterampilan, tenaga dan waktu untuk menyelenggarakan berbagai kegiatan yang menjadi tanggaung jawab dan menunaikan kewajibannya dalam rangka pencapaian. Sedangkan menurut Hasibuan (2005-193) menyatakan bahwa: Kedisiplinan adalah fungsi operatif keenam dari Manajemen Sumber Daya Manusia. Kedisiplin merupakan fungsi operatif MSDM yang terpenting karena semakin baik disiplin karyawan, semakin tinggi prestasi kerja dapat dicapainya. Tanpa disiplin karyawan yang baik, sulit bagi organisasi perusahaan mencapai hasil yang optimal.

Dari beberapa teori di atas, maka dapat disimpulkan bahwa tujuan pendisiplinan karyawan adalah menciptakan atau mempertahankan rasa hormat dan saling percaya di antara supervisi dengan bawahannya. Disiplin yang diberlakukan secara tidak tepat dapat menciptakan masalah-masalah seperti modal kerja yang rendah, kemarahan, dan kemauan buruk di antara pengawasan dan bawahan-bawahannya. Dalam kondisi seperti ini semua perbaikan dan perilaku pegawai hanya akan berlangsung singkat, dan pengawas harus mendisiplinkan kembali pegawai dalam jangka waktu yang tidak terlalu lama. Pelaksanaan tindakan disiplin yang benar tidak hanya memperbaiki perilaku pegawai, akan tetapi juga akan meminimalkan masalah-masalah pendisiplinan di masa yang akan datang melalui hubungan yang positif di antara bawahan dan atasan. Tindakan pendisiplinan juga dapat membantu pegawai supaya menjadi lebih produktif, dengan demikian dapat menguntungkannya dalam jangka waktu panjang.

D. Kinerja

Stephen P. Robbins (2001:6) menyebutkan bahwa secara sederhana Kinerja Pendidik adalah fungsi dari interaksi antara kemampuan (ability) dan Motivasi 
(motivation), tetapi masih ada bagian yang masih hilang dari fungsi tersebut selain kecerdasan dan keahlian dari seorang individu yang keduanya merupakan bagian dari kemampuan dan Motivasi dari setiap karyawan, yaitu kesempatan.

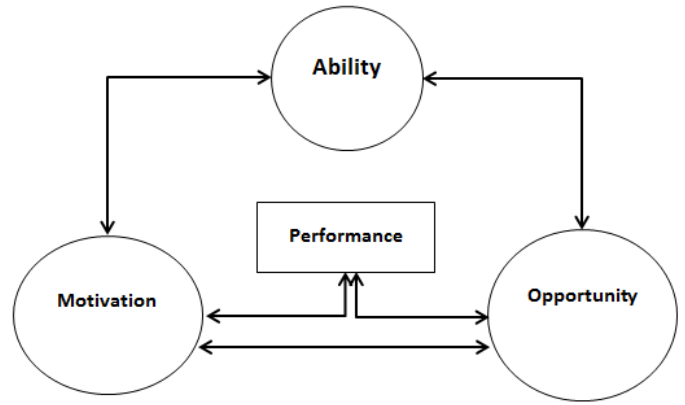

Sumber: Robbins (2001:6)

Gambar 2. Model dari performance

Kinerja individu didefinisikan sebagai kemampuan individu: dalam melalukan sesuatu dengan keahlian tertentu. Senada dengan pendapat tersebut, (Stephen Robbins dalam Sinambela, 2012:5) mengemukakan bahwa kinerja diartikan sebagai hasil evaluasi terhadap pekerjaan yang dilakukan individu dibandingkan dengan kriteria yang telah ditetapkan bersama. Kedua konsep di atas menunjukkan bahwa kinerja seseorang sangatlah perlu, sebab dengan kinerja ini akan diketahui seberapa jauh kemampuan seseorang dalam melaksanakan tugasnya. Untuk mengetahui hal itu diperlukan penentuan kriteria pencapaiannya yang ditetapkan secara bersama-sama.

Kinerja adalah hasil kerja yang dapat dicapai oleh seseorang atau sekelompok orang dalam suatu organisasi, sesuai dengan wewenang dan tanggungjawab masingmasing, dalam rangka upaya mencapai tujuan organisasi bersangkutan secara legal, tidak melanggar hukum dan sesuai dengan moral dan etika, (Prawirosentono dalam Sinambela, 2012:5). Rumusan di atas menjelaskan bahwa kinerja adalah tingkat keberhasilan seseorang atas lembaga dalam melaksanakan pekerjaannya. Dari definisi di atas, terdapat setidaknya empat elemen yaitu: (1) hasil kerja yang dicapai secara individual atau secara instansi, yang berarti bahwa kinerja tersebut adalah "hasil akhir" yang diperoleh secara sendiri - sendiri atau berkelompok (2) dalam melaksanakan tugas, orang atau lembaga diberikan wewenang Kinerja Pegawai; Teori, Pengukuran dan Implikasi dan tanggung jawab, yang berarti orang atau lembaga diberikan hak dan kekuasaan untuk bertindak dak sehingga pekerjaannya dapat dilakukan dengan baik meskipun demikian orang atau lembaga tersebut tetap harus dalam kendali, yakni mempertanggungjawabkan pekerjaannya kepada pemberi hak dan wewenang, sehingga dia tidak akan menyalahgunakan hak dan wewenangnya tersebut. (3) Pekerjaan haruslah dilakukan secara legal, yang berarti dalam melaksanakan tugas-tugas individu atau lembaga tentu saja harus mengikuti aturan yang telah ditetapkan, dan (4) Pekerjaan tidaklah bertentangan dengan moral aim, etika, artinya selain mengikuti aturan yang telah ditetapkan, tentu saja pekerjaan tersebut haruskah sesuai dengan moral dan etika yang berlaku umum.

Terdapat dua aspek penting yang perlu diperhatikan dalam mencapai kinerja kelompok yaitu Pertama, hubungan antara keterpaduan dengan kinerja kelompok. Kedua perbedaan-perbedaan antara pemecahan masalah dengan pengambilan keputusan secara individu dan kelompok. Oleh sebab itu keberhasilan atau kegagalan pegawai dalam menentukan tujuan-tujuan organisasi ditentukan oleh sebaik mana 
mereka memimpin kelompok secara terpadu. Dalam mengelola kelompok kedua aspek tersebut perlu diperhatikan oleh pimpinan.

Menurut Haynes membangun kinerja perlu memperhatikan empat elemen pendekatan yang sistematik, seperti diperlihatkan dalam gambar berikut:

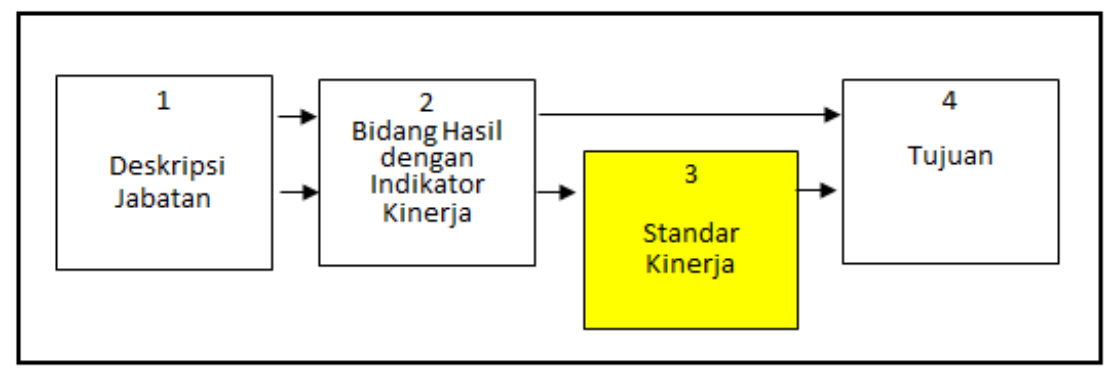

Sumber:Sinambela, 2012:7

Gambar 3. Elemen Suatu Pendekatan Sistematik untuk Menimbulkan Harapan Kinerja

Gambar di atas menunjukkan bahwa untuk memperoleh kinerja yang baik, harus memperhatikan empat elemen pokok yaitu deskripsi jabatan, yang akan menguraikan tugas dan tanggungjawab suatu jabatan, sehingga pejabat yang akan melakukannya tahu secara pasti apa yang harus dilakukannya. Misalnya, untuk meningkatkan kinerja seorang guru, tentu saja guru tersebut harus tahu apa yang harus dilakukannya, bagaimana melakukannya. Bidang hasil dengan indikator kineja haruslah jelas, artinya seorang guru harusnya mengetahui indikator keberhasilan tugas-tugasnya. Selain penetapan indikator pelaksanaan tugas yang dilakukan tersebut. Degan melaksanakan ketiga element tersebut secara sistematis diharapkan tujuan yang sudah ditetapkan tersebut akan dapat dicapai.

Dengan demikian kesimpulan kinerja adalah kesediaan seseorang atau kelompok orang untuk melakukan suatu kegiatan yang menyempurnakannya sesuai dengan tanggungjawabnya dengan hasil seperti yang diharapkan jika dikaitkan dengan kinerja sebagai kata benda di mana salah satu entrinya adalah hasil dari sesuatu pekerjaan pengertian kiner ${ }_{j}$ a adalah hasil kerja yang dapat dicapai oleh seseorang atau kelompok orang oleh suatu perusahaan sesuai dengan wewenang dan tanggung jawab masing-masing dalam upaya pencapaian tujuan perusahaan secara legal, tidak melanggar hukum dan tidak bertentangan dengan moral atau etika.

\section{METODOLOGI PENELITIAN}

A. Tempat dan Waktu Penelitian

Penelitian dilaksanakan di Yayasan Marvin, sebuah yayasan yang bergerak di bidang pendidikan anak berkebutuhan khusus, Jalan Cikatomas 1 no. 33, Kebayoran Baru Jakarta Selatan.

B. Metode Penelitian

Pendekatan analisis yang dipakai dalam penelitian ini adalah menggunakan pendekatan kuantitatif, jenis statistik yang dipakai dalam penelitian adalah statistik non parametrik. Menurut (Sugiyono, 2007:224): "Statistik non parametrik digunakan untuk menguji hipotesis bila datanya berbentuk nominal atau ordinal, 
dan tidak berlandaskan asumsi bahwa distribusi data harus normal". Peneliti menggunakan statistik nonparametrik karena data yang diolah berbentuk ordinal.

C. Desain Penelitian

Desain yang digunakan dalam penelitian ini bersifat deskriptif kuantitatif dengan tujuan mengetahui seberapa besar pengaruh gaya kepemimpinan, Motivasi dan disiplin kerja terhadap kinerja pendidik yayasan Marvin.

D. Definisi Operasional Variabel

1. Definisi Operasional Variabel

Definisi operasional yang digunakan dalam penelitian ini kemudian diuraikan menjadi indikator empiris yang meliputi:

a. Kinerja Pendidik

Kinerja Pendidik adalah perbandingan hasil kerja nyata karyawan dengan standar kerja yang telah ditetapkan oleh sekolah.

b. Gaya kepemimpinan

Gaya kepemimpinan merupakan cara pemimpin memanfaatkan kekuatan yang tersedia untuk memimpin para karyawannya, (Likret dalam Handoko 2003: 301) mengemukakan dua kategori gaya dasar ini, orientasi karyawan dan orientasi tugas, menyusun suatu model empat tingkat efektifitas manajemen.

c. Motivasi

Motivasi merupakan faktor yang mempengaruhi semangat dan kegairahan kerja karyawan untuk berperan serta secara aktif dalam proses kerja.

2. Variabel Penelitian

Variabel penelitian adalah hal-hal yang dapat membedakan atau membawa variasi pada nilai. Penelitian ini menggunakan dua variabel yaitu variabel independen dan variabel dependen.

3. Penentuan Populasi dan Sampel

Populasi dalam penelitian ini adalah seluruh karyawan yang ada di yayasan Marvin yang berjumlah 112 karyawan. Mengingat jumlah populasi hanya sebesar 112 karyawan, maka layak untuk diambil keseluruhan untuk dijadikan sampel tanpa harus mengambil sampel dalam jumlah tertentu. Sehingga sampel dari penelitian ini adalah seluruh karyawan Yayasan Marvin.

E. Sumber dan Cara Pengumpulan data/Informasi

1. Sumber Data

Sumber data yang digunakan dalam penelitian ini terdiri dari dua macam yaitu data primer dan data sekunder.

2. Cara Pengumpulan Data/Informasi

Metode pengumpulan data yang digunakan dalam penelitian ini adalah: Kuesioner, Observasi dan Studi Pustaka.

F. Teknik Penentuan Data

Sebelum melakukan analisis data, maka perlu dilakukan tahap-tahap teknik pengolahan data sebagai berikut: Editing, Coding, Scoring, Tabulating , kemudian diolah dengan program komputer SPSS 17. 
G. Rancangan Analisis dan Uji Hipotesis

1. Rancangan Analisis

a. Uji Validitas

Uji validitas digunakan untuk mengukur sah atau valid tidaknya suatu kuesioner. Suatu kuesioner dikatakan valid jika pertanyaan pada kuesioner mampu untuk mengungkapkan sesuatu yang akan diukur oleh kuesioner tersebut

b. Uji Reliabilitas

Uji reliabilitas merupakan alat untuk mengukur suatu kuesioner yang merupakan indikator dari variabel atau konstruk. Suatu kuesioner dikatakan reliable atau handal jika jawaban seseorang terhadap pernyataan adalah konsisten atau stabil dari waktu ke waktu.

c. Uji Asumsi Klasik

Untuk meyakinkan bahwa persamaan garis regresi yang diperoleh adalah linier dan dapat dipergunakan (valid) untuk mencari peramalan, maka akan dilakukan pengujian asumsi multikolinearitas, heteroskedastisitas, dan normalitas.

d. Analisis Regresi Linier Berganda

Analisis ini digunakan untuk mengetahui seberapa besar pengaruh variabel bebas yaitu: gaya kepemimpinan (X1), Motivasi (X2), dan disiplin kerja (X3) terhadap variabel terikatnya yaitu Kinerja Pendidik $(Y)$. Persamaan regresi linier berganda adalah sebagai berikut: $Y=a+b 1 X 1+b 2 X 2+b 3 X 3+e$

2. Uji Hipotesis
a. Uji Signifikansi Simultan ( Uji Statistik F )
Dalam penelitian ini, uji $\mathrm{F}$ digunakan untuk mengetahui tingkat siginifikansi pengaruh variabel-variabel independen secara bersama-sama (simultan) terhadap variabel dependen
b. Analisis Koefisien Determinasi $\left(\mathrm{R}^{2}\right)$
Koefisien determinasi $\left(R^{2}\right)$ pada intinya mengukur seberapa jauh kemampuan model dalam menerangkan variasi variabel terikat. Nilai Koefisien determinasi adalah antara nol dan satu. Nilai $R^{2}$ yang kecil berarti kemampuan variabel-variabel bebas (gaya kepemimpinan, Motivasi dan disiplin kerja) dalam menjelaskan variasi variabel terikat (Kinerja Pendidik) amat terbatas.

\section{HASIL DAN PEMBAHASAN}

A. Pengujian Persyaratan Analisis

1. Uji Validitas

a. Uji Validitas Gaya Kepemimpinan

Tabel 1 : Analisa Uji Validitas Variabel Gaya Kepemimpinan

\begin{tabular}{|c|c|c|c|c|}
\hline \multicolumn{5}{|c|}{ Validitas Gaya Kepemimpinan } \\
\hline No & Pertanyaan & r- hitung $^{\mid}$ & r- tabel & Kesimpulan \\
\hline 1 & Kuesioner 1 & 0.523 & 0.184 & Valid \\
\hline 2 & Kuesioner 2 & 0.304 & 0.184 & Valid \\
\hline 3 & Kuesioner 3 & 0.499 & 0.184 & Valid \\
\hline 4 & Kuesioner 4 & 0.491 & 0.184 & Valid \\
\hline 5 & Kuesioner 5 & 0.227 & 0.184 & Valid \\
\hline 6 & Kuesioner 6 & 0.320 & 0.184 & Valid \\
\hline 7 & Kuesioner 7 & 0.428 & 0.184 & Valid \\
\hline 8 & Kuesioner 8 & 0.329 & 0.184 & \\
\hline
\end{tabular}


Berdasarkan hasil uji validitas yang dilakukan dengan menggunakan program SPSS, menunjukan bahawa istrumen yang digunakan oleh peneliti sudah memenuhi sayarat untuk digunakan dalam penelitian.

b. Uji Validitas Motivasi

Tabel 2 : Analisa Uji Validitas Variabel Motivasi

\begin{tabular}{|c|c|c|c|c|}
\hline \multicolumn{5}{|c|}{ Validitas Motivasi } \\
\hline No & Pertanyaan & $\mathrm{r}$ - hitung & $\mathrm{r}$ - tabel & Kesimpulan \\
\hline 1 & Kuesioner 1 & 0.418 & 0.184 & Valid \\
\hline 2 & Kuesioner 2 & 0.524 & 0.184 & Valid \\
\hline 3 & Kuesioner 3 & 0.540 & 0.184 & Valid \\
\hline 4 & Kuesioner 4 & 0.482 & 0.184 & Valid \\
\hline 5 & Kuesioner 5 & 0.531 & 0.184 & Valid \\
\hline 6 & Kuesioner 6 & 0.474 & 0.184 & Valid \\
\hline 7 & Kuesioner 7 & 0.285 & 0.184 & Valid \\
\hline 8 & Kuesioner 8 & 0.339 & 0.184 & Valid \\
\hline 9 & Kuesioner 9 & 0.226 & 0.184 & Valid \\
\hline 10 & Kuesioner 10 & 0.215 & 0.184 & Valid \\
\hline
\end{tabular}

Sumber: Hasil Olah Data Premier

\section{c. Uji Validitas Disiplin Kerja}

Tabel 3 : Analisa Uji Validitas Variabel Disiplin Kerja

\begin{tabular}{|c|c|c|c|c|}
\hline \multicolumn{5}{|c|}{ Validitas Motivasi } \\
\hline No & Pertanyaan & r- hitung & r- tabel & Kesimpulan \\
\hline 1 & Kuesioner 1 & 0.255 & 0.184 & Valid \\
\hline 2 & Kuesioner 2 & 0.461 & 0.184 & Valid \\
\hline 3 & Kuesioner 3 & 0.401 & 0.184 & Valid \\
\hline 4 & Kuesioner 4 & 0.427 & 0.184 & Valid \\
\hline 5 & Kuesioner 5 & 0.354 & 0.184 & Valid \\
\hline 6 & Kuesioner 6 & 0.393 & 0.184 & Valid \\
\hline 7 & Kuesioner 7 & 0.359 & 0.184 & Valid \\
\hline 8 & Kuesioner 8 & 0.336 & 0.184 & Valid \\
\hline 9 & Kuesioner 9 & 0.267 & 0.184 & Valid \\
\hline 10 & Kuesioner 10 & 0.463 & 0.184 & \\
\hline
\end{tabular}

Sumber: Hasil Olah Data Premier

d. Uji Validitas Kinerja Pendidik

Tabel 4 : Analisa Uji Validitas Variabel Kinerja Pendidik

\begin{tabular}{|c|c|c|c|c|}
\hline \multicolumn{5}{|c|}{ Validitas Kinerja Pendidik } \\
\hline No & Pertanyaan & $r^{-}$hitung & $r^{-}$tabel & Kesimpulan \\
\hline 1 & Kuesioner 1 & 0.367 & 0.184 & Valid \\
\hline 2 & Kuesioner 2 & 0.424 & 0.184 & Valid \\
\hline 3 & Kuesioner 3 & 0.271 & 0.184 & Valid \\
\hline 4 & Kuesioner 4 & 0.532 & 0.184 & Valid \\
\hline 5 & Kuesioner 5 & 0.363 & 0.184 & Valid \\
\hline 6 & Kuesioner 6 & 0.498 & 0.184 & Valid \\
\hline
\end{tabular}


JURNAL ILMIAH ILMU MANAJEMEN

\begin{tabular}{|c|c|c|c|c|}
7 & Kuesioner 7 & 0.455 & 0.184 & Valid \\
\hline 8 & Kuesioner 8 & 0.341 & 0.184 & Valid \\
\hline 9 & Kuesioner 9 & 0.214 & 0.184 & Valid \\
\hline 10 & Kuesioner 10 & 0.239 & 0.184 & Valid \\
\hline 11 & Kuesioner 11 & 0.222 & 0.184 & Valid \\
\hline 12 & Kuesioner 12 & 0.441 & 0.184 & Valid \\
\hline
\end{tabular}

Sumber: Hasil Olah Data Premier

2. Uji Reliabilitas

Tabel 5 : Uji Reliabilitas Variabel $\mathrm{X}_{1}, \mathrm{X}_{2}, \mathrm{X}_{3}$ dan $\mathrm{Y}$

\begin{tabular}{|c|l|c|c|c|}
\hline No & Variabel & Alpa Cronbach & Nilai $r_{\text {tabel }}$ & Ket \\
\hline 1 & Gaya Kepemimpinan & 0.205 & 0.184 & Reliabel \\
\hline 2 & Motivasi & 0.433 & 0.184 & Reliabel \\
\hline 3 & Displin Kerja & 0.253 & 0.184 & Reliabel \\
\hline 4 & Kinerja Pendidik & 0.417 & 0.184 & Reliabel \\
\hline
\end{tabular}

Sumber: Hasil Olah Data Premier

3. Uji Asumsi Klasik

a. Uji Normalitas Data

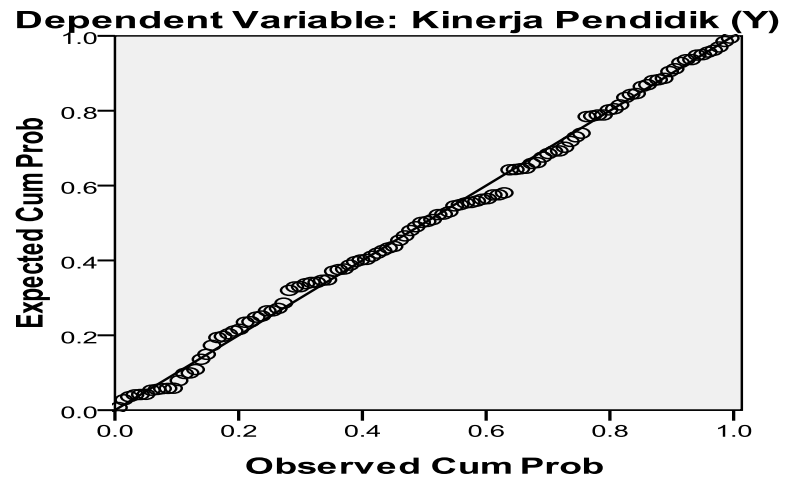

Gambar 4. Grafik Normal P-plot

Dari hasil pengujian normalitas diatas dapat dilihat bahwa data menyebar disekitar garis diagonal dan mengikuti arah garis diagonal, maka data terdistribusi dengan normal dan model regresi telah memenuhi asumsi normalitas.

b. Uji Multikolinearitas

Tabel 6 : Hasil Uji Multikolinearitas

\begin{tabular}{|c|c|c|c|c|c|c|c|}
\hline \multirow[t]{2}{*}{ Model } & \multicolumn{2}{|c|}{$\begin{array}{c}\text { Unstandardized } \\
\text { Coefficients }\end{array}$} & \multirow{2}{*}{$\begin{array}{l}\begin{array}{l}\text { Standardized } \\
\text { Coefficients }\end{array} \\
\text { Beta }\end{array}$} & \multirow[t]{2}{*}{$\mathrm{t}$} & \multirow[t]{2}{*}{ Sig. } & \multicolumn{2}{|c|}{$\begin{array}{c}\text { Collinearity } \\
\text { Statistics }\end{array}$} \\
\hline & B & Std. Error & & & & Tolerance & VIF \\
\hline $\begin{array}{ll}1 & \text { (Constant) }\end{array}$ & 7,101 & 4,272 & & 1,662 & 099 & & \\
\hline $\begin{array}{l}\text { Gaya Kepemim- } \\
\text { pinan }(\mathrm{X} 1)\end{array}$ & ,983 & , 194 & 659 & 10,494 &, 003 & ,929 & 1,076 \\
\hline Motivas (X2) & ,276 & , 168 & ,072 & 1,897 &, 005 & ,992 & 1,008 \\
\hline Disiplin Kerja (X3) &, 257 &, 181 & , 128 & 1,931 & ,004 & ,929 & 1,077 \\
\hline
\end{tabular}

a. dependent variabel: Kinerja Pendidik (Y),

Sumber: Hasil Olah Data Premier 
Dari tabel diatas dapat dilihat bahwa tidak ada satupun variabel yang memiliki VIF lebih dari 10 dan tidak ada yang memiliki tolerance value lebih kecil dari 0,1 . Jadi dapat disimpulkan dalam penelitian ini bebas dari adanya multikolinearitas dari hasil analisis didapat nilai VIF untuk variabel Gaya Kepemimpinan adalah 1,076 $(\leq 10)$ dan nilai tolerance value sebesar $0,929(\geq 0,1)$. Nilai VIF untuk variabel Motivasi adalah $1,008(\leq 10)$ dan nilai tolerance value nya $0,992(\geq 0,1)$. Nilai VIF untuk variabel Displin Kerja adalah 1,077 $(\leq 10)$ dan nilai tolerance value nya sebesar $0,929(\geq 0,1)$. Hasil ini dapat disimpulkan bahwa semua variabel bebas yang dipakai dalam penelitian ini lolos uji gejala multikolinearitas.

\section{c. Uji Heteroskedastisitas}

Pengujian heteroskedastisitas dapat dilakukan dengan uji grafik dengan melihat grafik scatterplot yaitu dengan cara melihat titik-titik penyebaran pada grafik dan uji glejer dengan cara meregres seluruh variabel independen dengan nilai absolute residual (absut) sebagai variabel dependennya.

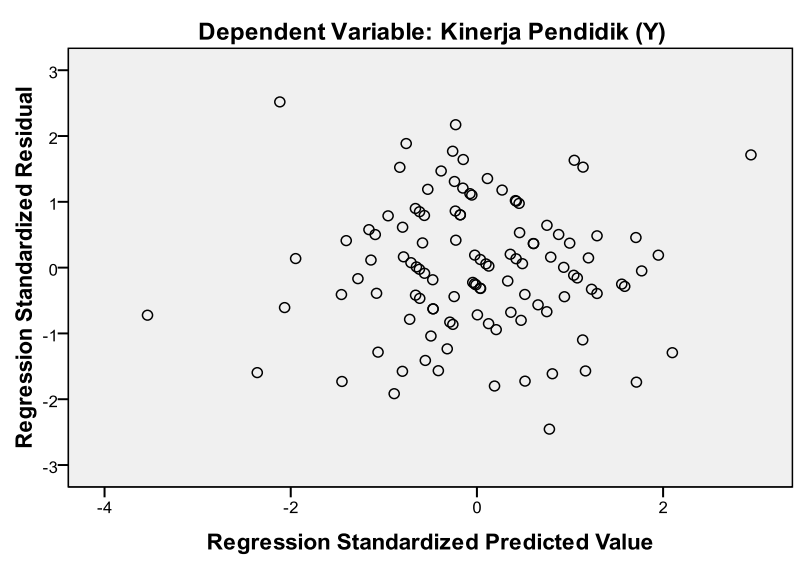

Gambar 6. Grafik Scatterplot

Gambar 6 scatterplots diatas dapat diketahui bahwa titik-titik menyebar dengan pola yang tidak jelas diatas dan dibawah 0 pada sumbu Y, maka model regresi tidak terjadi masalah heteroskedastisitas.

\section{d. Analisis Regresi Berganda}

Berdasarkan regresi berganda tersebut menggunakan program SPSS (Statistical Product and Service Solutions ) versi 17 for window diperoleh hasil sebagai berikut:

Tabel 7 : Hasil Regresi Berganda

\begin{tabular}{|l|l|c|c|c|c|c|}
\hline \multicolumn{2}{|c|}{ Model } & \multicolumn{2}{|c|}{$\begin{array}{c}\text { Unstandardized } \\
\text { Coefficients }\end{array}$} & $\begin{array}{c}\text { Standardized } \\
\text { Coefficients }\end{array}$ & \multirow{2}{*}{$\mathrm{t}$} & \multirow{2}{*}{ Sig. } \\
\cline { 3 - 5 } \multicolumn{2}{|c|}{} & B & Std. Error & Beta & & \\
\hline 1 & (Constant) & 7,101 & 4,272 & & 1,662 &, 099 \\
& Gaya Kepemimpinan (X1) &, 983 &, 194 &, 695 & 10,494 &, 003 \\
& Motivasi (X2) &, 276 &, 168 &, 072 & 1,897 &, 005 \\
& Disiplin Kerja (X3) &, 257 &, 181 &, 128 & 1,931 &, 004 \\
\hline
\end{tabular}

a. dependent variabel: Kinerja Pendidik

Sumber: Hasil Olah Data Premier 
Dari hasil perhitungan data diatas dapat disajikan kedalam bentuk persamaan regresi standardized sebagai berikut:

Keterangan:

$$
Y=7,101+0,983 X_{1}+0,276 X_{2}+0,257 X_{3}
$$

$$
\begin{array}{ll}
\mathrm{Y} & =\text { Kinerja Pendidik } \\
\mathrm{X}_{1} & =\text { Variabel Gaya Kepemimpinan } \\
\mathrm{X}_{2} & =\text { Variabel Motivasi } \\
\mathrm{X}_{3} & =\text { Variabel Disiplin Kerja }
\end{array}
$$

Berdasarkan hasil persamaan regresi berganda tersebut, dapat dilihat bahwa koefisiensi regresi yang diperoleh bertanda positif, hal ini menunjukan bahwa variabel Gaya Kepemimpinan, Motivasi dan Disiplin Kerja mempunyai pengaruh yang positif terhadap Kinerja Pendidik, dimana setiap ada peningkatan variabel Gaya Kepemimpinan, Motivasi dan Disiplin Kerja maka akan meningkatkan pula Kinerja Pendidik untuk untuk dapat bekerja dengan baik dan sesuai dengan ketentuan perusahaan.

Adapun persamaan tersebut dijelaskan sebagai berikut:

1) Konstanta (a) sebesar 7,101 menyatakan bahwa tanpa variabel Gaya Kepemimpinan, Motivasi dan Disiplin Kerja, besarnya nilai Kinerja Pendidik tetap terbentuk sebesar 7,101.

2) Variabel Gaya Kepemimpinan $\left(x_{1}\right)$ berpengaruh positif terhadap Kinerja Pendidik $(y)$ dengan nilai koefisiensi sebesar 0,983. Yang artinya jika variabel Gaya Kepemimpinan $\left(\mathrm{x}_{1}\right)$ meningkat satu satuan dengan asumsi variabel Motivasi $\left(\mathrm{x}_{2}\right)$ dan Disiplin Kerja $\left(x_{3}\right)$ tetap, maka Kinerja Pendidik $(y)$ akan meningkat sebesar 0,983.

3) Variabel Motivasi $\left(x_{2}\right)$ berpengaruh positif terhadap Kinerja Pendidik ( $y$ ) dengan nilai koefisien sebesar 0,276 yang artinya jika variabel Motivasi $\left(x_{2}\right)$ meningkat satu satuan dengan asumsi variabel Gaya Kepemimpinan $\left(\mathrm{x}_{1}\right)$ dan variabel Disiplin Kerja $\left(x_{3}\right)$ tetap, maka Kinerja Pendidik (y) akan meningkat sebesar 0,276.

4) Variabel Disiplin Kerja ( $x 3$ ) berpengaruh positif terhadap Kinerja Pendidik (y) dengan nilai koefisien sebesar 0,257 yang artinya jika variabel Disiplin Kerja ( $\times 3)$ meningkat satu satuan dengan asumsi variabel Gaya Kepemimpinan (x1) dan variabel Motivasi (x2) tetap, maka Kinerja Pendidik akan meningkat sebesar 0,257.

4. Uji Hipotesis

\section{a. Uji Hipotesis Parsial}

Perlu dilakukan uji signifikansi dengan menggunakan uji statistik (uji t) dengan menggunakan taraf siginifikansi sebsar $5 \%(0,05)$ dan derajat kebebasan (dk) korelasi dengan rumus: $\mathrm{dk}=\mathrm{n}-\mathrm{k}-1$, dimana $n$ adalah jumlah responden, dan $k$ adalah jumlah variabel yang diteliti. Langkah-langkah pengujianya sebagai berikut :

1) Menentukan Formula Hipotesis:

a) Gaya Kepemimpinan

$\mathrm{H}_{\mathrm{a} 1}$ : Diduga terdapat pengaruh positif dan signifikan gaya kepemimpinan terhadap kinerja pendidik

$\mathrm{H}_{01}$ : Diduga tidak terdapat pengaruh positif dan signifikan gaya kepemimpinan terhadap kinerja pendidik 
b) Motivasi

$\mathrm{H}_{\mathrm{a} 2}$ : Diduga terdapat pengaruh positif dan signifikan motivasi terhadap kinerja pendidik

$\mathrm{H}_{02}$ : Diduga tidak terdapat pengaruh positif dan signifikan motivasi terhadap kinerja pendidik

c) Disiplin Kerja

$\mathrm{H}_{\mathrm{a} 3}$ : Diduga terdapat pengaruh positif dan signifikan disiplin kerja terhadap kinerja pendidik

$\mathrm{H}_{03}$ : Diduga tidak terdapa pengaruh positif dan signifikan disiplin kerja terhadap kinerja pendidik

2. Menentukan Drajat Kepercayaan yaitu $95 \%(a=0,05)$

3. Menentukan Signifikansi

Nilai signfikansi ( $p$ value) $<0,05$ maka $\mathrm{H}_{\mathrm{O}}$ ditolak dan $\mathrm{H}_{\mathrm{a}}$ diterima

Nilai signifikansi ( $p$ value) $>0,05$ maka $\mathrm{H}_{\mathrm{O}}$ diterima dan $\mathrm{H}_{\mathrm{a}}$ ditolak

4. Membuat Kesimpulan

Dasar pengambilan keputusan (Ghozali, 2005:84) adalah dengan menggunakan angka probabilitas signifikansi, yaitu:

a. Apabila angka probabilitas signifikani $>0.05$ dan $t$ hitung $<\mathrm{t}$ tabel maka $\mathrm{H}_{\mathrm{o}}$ diterima dan $\mathrm{H}_{\mathrm{a}}$ ditolak.

b. Apabila angka probabilitas signifikansi $<0.05$ dan $t$ hitung $>t$ tabel maka $\mathrm{H}_{\mathrm{o}}$ ditolak dan $\mathrm{H}_{\mathrm{a}}$ diterima.

Dimana drajat kebebasan (dk) ialah:

$\mathrm{dk}=\mathrm{n}-\mathrm{k}-1 ; \mathrm{dk}=112-3-1 ; \mathrm{dk}=110$

Statistik tabel :

$\alpha=5 \%(0,05) ; \mathrm{t} \alpha=\mathrm{t}(\alpha ; \mathrm{dk}) ; \mathrm{t} \alpha=(0,05 ; 110)=1,98498$ atau 1,98

Adapun hasi uji hipotesis dengan menggunaka program SPSS ialah sebagai berikut:

a. Uji Hipotesis Gaya Kepemimpinan

$\mathrm{H}_{\mathrm{a} 1}$ : Diduga terdapat pengaruh positif dan signifikan gaya kepemimpinan terhadap kinerja pendidik

$\mathrm{H}_{01}$ : Diduga tidak terdapat pengaruh positif dan signifikan gaya kepemimpinan terhadap kinerja pendidik

Tabel 8 : Uji t Hipotesis $\mathrm{H}_{1}$

\begin{tabular}{|c|c|c|c|c|c|}
\hline \multirow{2}{*}{ Model } & \multicolumn{2}{|c|}{$\begin{array}{c}\text { Unstandardized } \\
\text { Coefficients }\end{array}$} & $\begin{array}{c}\text { Standardized } \\
\text { Coefficients }\end{array}$ & & \\
\cline { 2 - 4 } & $\mathrm{B}$ & Std. Error & Beta & $\mathrm{t}$ & Sig. \\
\hline $1 \quad$ (Constant) & 5,853 & 2,050 & & 2,855 &, 005 \\
Gaya Kepemimpinan (X1) &, 513 &, 046 &, 734 & 11,323 &, 003 \\
\hline
\end{tabular}

a. dependent variable: Kinerja Pendidik (Y)

Sumber: Hasil Olah Data Premier

Berdasarkan table tersebut dapat dilihat bahawa variabel gaya kepemimpinan diperoleh nilai signifikansi $t$ lebih kecil dari 0,05 atau 0,003 $<0,05$ dan $t_{\text {hitung }} 11,323>t$ table 1,98 , maka $\mathrm{H}_{01}$ ditolah dan $\mathrm{H}_{\mathrm{a} 1}$ diterima, hal ini menunjukan bahwa terdapat pengaruh yang postif dan signifikan dari gaya kepemimpinan terhadap kinerja pendidik. 
b. Uji Hipotesis Motivasi

$\mathrm{H}_{\mathrm{a} 2}$ : diduga terdapat pengaruh positif dan signifikan Motivasi terhadap kinerja pendidik

$\mathrm{H}_{02}$ : diduga tidak terdapat pengaruh positif dan signifikan motivasi terhadap kinerja pendidik.

Tabel 9 : Uji t Hipotesis $\mathrm{H} 2$

\begin{tabular}{|c|c|c|c|c|c|}
\hline \multirow{2}{*}{ Model } & \multicolumn{2}{|c|}{ Unstandardized Coefficients } & Standardized Coefficients & \multirow[b]{2}{*}{$\mathrm{t}$} & \multirow[b]{2}{*}{ Sig. } \\
\hline & $B$ & Std. Error & Beta & & \\
\hline $1 \quad$ (Constant) & 39,230 & 3,959 & & 9,909 & ,000 \\
\hline Motivasi (X2) & ,138 & ,101 & ,129 & 2,367 & ,004 \\
\hline
\end{tabular}

a. dependent variable: Kinerja Pendidik (Y)

Sumber: Hasil Olah Data Premier

Berdasarkan table tersebut dapat dilihat bahawa variabel motivasi diperoleh nilai signifikansi $t$ lebih kecil dari 0,05 atau 0,004 $<0,05$ dan $t$ hitung 2,367 $>t_{\text {table }} 1,98$, maka $\mathrm{H}_{02}$ ditolah dan $\mathrm{H}_{\mathrm{a} 2}$ diterima, hal ini menunjukan bahwa terdapat pengaruh yang postif dan signfikan dari motivasi terhadap kinerja pendidik.

c. Uji Hipotesis Disiplin Kerja

$\mathrm{H}_{\mathrm{a} 3}$ : Diduga terdapat pengaruh positif dan signifikan disiplin kerja terhadap kinerja pendidik

$\mathrm{H}_{03}$ : Diduga tidak terdapa pengaruh positif dan signifikan disiplin kerja terhadap kinerja pendidik

Tabel 10. : Uji t Hipotesis H3

\begin{tabular}{|c|c|c|c|c|c|}
\hline \multirow{2}{*}{ Model } & \multicolumn{2}{|c|}{ Unstandardized Coefficients } & Standardized Coefficients & & \\
\cline { 2 - 5 } & $\mathrm{B}$ & Std. Error & Beta & $\mathrm{t}$ & Sig. \\
\hline $1 \quad$ (Constant) & 29,812 & 4,269 & & 6,983 &, 000 \\
Disiplin Kerja (X3) &, 387 &, 111 &, 315 & 3,479 &, 001 \\
\hline
\end{tabular}

a. dependent variable: Kinerja Pendidik

Sumber: Hasil Olah Data Premier

Berdasarkan table tersebut dapat dilihat bahawa variabel disiplin kerja diperoleh nilai signifikansi $t$ lebih kecil dari 0,05 atau 0,001 $<0,05$ dan $t_{\text {hitung }} 3,479>t_{\text {table }} 1,98$, maka $\mathrm{H}_{03}$ ditolah dan $\mathrm{H}_{\mathrm{a}}$ diterima, hal ini menunjukan bahwa terdapat pengaruh yang postif dan signfikan dari disiplin kerja terhadap kinerja pendidik.

d. Uji Hipotesis Simultan

$\mathrm{H}_{\mathrm{a} 4}$ : Diduga terdapat pengaruh positif dan signifikan Gaya kepemimpinan, motivasi dan disiplin kerja terhadap kinerja pendidik

$\mathrm{H}_{04}$ : Diduga tidak terdapat pengaruh positif dan Signifikan gaya kepemimpinan, motivasi dan disiplin kerja terhadap kinerja pendidik

$\mathrm{F}_{\text {hitung }}$ dan $\mathrm{F}_{\text {tabel }}$

$F_{\text {hitung }}$ adalah 45,737 (lihat pada tabel anova)

$\mathrm{F}_{\text {tabel }}$ dapat dicari pada tabel statistik pada signifikansi 0,05:

df $1=\mathrm{k}-1$ atau $4-1=3$, dan df $2=n-k$ atau $112-4=108$ 
( $\mathrm{k}$ adalah jumlah variabel), di dapat $\mathrm{F}_{\text {tabel }}$ adalah 2,69

Adapun hasil uji $\mathrm{F}$ dengan pengolahan SPSS versi 17 for windows dapat dilihat pada tabel dibawah ini:

Tabel 11 : Hasil Uji F

\begin{tabular}{|l|c|c|c|c|c|}
\hline Model & Sum of Squares & df & Mean Square & $\mathrm{F}$ & Sig. \\
\hline \multirow{3}{*}{1 Regression } & 714,146 & 3 & 238,049 & 45,737 &, $001^{\text {a }}$ \\
Residual & 562,104 & 108 & 5,205 & & \\
Total & 1276,250 & 111 & & & \\
\hline
\end{tabular}

a. predictors: (Constanta), Disiplin Kerja (X3), Motivasi (X2), Gaya Kepemimpinan (X1)

b. dependent variable: Kinerja Pendidik (Y)

Sumber: Hasil Olah Data Premier

Dari hasil uji anova pada tabel diatas dapat diperoleh signifikansi 0,001<0,05 dan $\mathrm{F}_{\text {hitung }} 45,737>\mathrm{F}_{\text {tabel }}$ 2,69 maka, $\mathrm{H}_{04}$ ditolak dan $\mathrm{H}_{\mathrm{a} 4}$ diterima, hal ini menunjukan bahwa terdapat pengaruh yang positif dan signifikan dari gaya kepemimpinan, motivasi dan disiplin kerja terhadap kinerja pendidik.

5. Analasis Koefisiensi Determinasi

Untuk mengetahui besarnya pengaruh variabel gaya kepemimpinan, motivasi dan disiplin kerja secara parsial ataupun bersama-sama terhadap Kinerja Pendidik sebagai berikut:

a. Untuk mengetahui besarnya pengaruh gaya kepemimpinan terhadap Kinerja Pendidik, dapat dilihat pada tabel dibawah ini:

Tabel 12 : Hasil Uji Determinasi Gaya Kepemimpinan

\begin{tabular}{|l|l|l|l|l|}
\hline Model & $\mathrm{R}$ & $\mathrm{R}$ Square & Adjusted R Square & Std. Error of the Estimate \\
\hline 1 & $.734^{\mathrm{a}}$ &, 538 &, 534 & 1,637 \\
\hline
\end{tabular}

1) predictor: (constant) gaya kepemimpinan (X1)

2) dependent variabel: Kinerja Pendidik (Y)

Sumber: Hasil Olah Data Premier

Dari tabel diatas dapat dilihat bahwa nilai R Square sebesar 0,538 atau $53,8 \%$. Hal ini menunjukan bahwa pengaruh gaya kepemimpinan terhadap Kinerja Pendidik sebesar $53,8 \%$.

b. Untuk mengetahui besarnya pengaruh motivasi terhadap Kinerja Pendidik

Tabel 13 : Hasil Uji Determinasi Motivasi

\begin{tabular}{|l|l|l|l|l|}
\hline Model & $\mathrm{R}$ & R Square & Adjusted R Square & Std. Error of the Estimate \\
\hline 1 & $.129^{\mathrm{a}}$ &, 170 &, 008 & 3,378 \\
\hline
\end{tabular}

a. predictor: (constant) motivasi (X2)

b. dependent variabel: kinerja karayawan (Y)

Sumber: Hasil Olah Data Premier

Dari tabel diatas dapat dilihat bahwa nilai $\mathrm{R}$ Square sebesar 0,17 atau $17 \%$. Hal ini menunjukan bahwa pengaruh motivasi terhadap Kinerja Pendidik sebesar 17\%. 
c. Untuk mengetahui besarnya pengaruh disipilin kerja terhadap Kinerja Pendidik

Tabel 14 : Hasil Uji Determinasi Displin Kerja

\begin{tabular}{|l|l|l|l|l|}
\hline Model & R & R Square & Adjusted R Square & Std. Error of the Estimate \\
\hline 1 & $.315^{\text {a }}$ &, 299 &, 091 & 3,233 \\
\hline
\end{tabular}

a. predictor: (constant) displin kerja $(\mathrm{X} 3)$

b. dependent variabel: Kinerja Pendidik (Y)

Sumber: Hasil Olah Data Premier

Dari tabel diatas dapat dilihat bahwa nilai $R$ Square sebesar 0,299. Hal ini menunjukan bahwa pengaruh disiplin kerja terhadap Kinerja Pendidik sebesar 29,9\%.

d. Untuk mengetahui besarnya pengaruh gaya kepemimpinan, motivasi dan disiplin kerja terhadap kinerja keyawan, dapat dilihat pada tabel:

Tabel 15 : Hasil Uji Determinasi

\begin{tabular}{|l|l|l|l|l|}
\hline Model & R & R Square & Adjusted R Square & Std. Error of the Estimate \\
\hline 1 & $.748^{\mathrm{a}}$ &, 560 &, 5477 & 2,281 \\
\hline
\end{tabular}

a. predictor: (constant) disiplin kerja (X3), motivasi (X2), gaya kepemimpinan (X3)

b. dependent variabel: Kinerja Pendidik (Y)

Sumber: Hasil Olah Data Premier

Besarnya nilai $\mathrm{R}$ Square berdasarkan hasil analisis dengan menggunakan SPSS versi 17 for windows diperoleh sebesar 0,560. Dengan demikian besarnya pengaruh yang diberikan oleh variabel gaya kepemimpinan, motivasi dan disiplin kerja terhadap Kinerja Pendidik adalah 56,0 \%, sedangkan sisanya 44,0 \% dipengaruhi oleh faktor lain yang tidak diteliti dalam penelitian ini.

\section{KESIMPULAN}

Dari data primer yang diperoleh dari penyebaran kuesioner maka dilakukan pengujian reliabilitas untuk mengetahui bahwa jawaban responden terhadap pernyataan konsisten dari waktu ke waktu. Dan dilakukan pengujian validitas untuk mengukur sah tidaknya suatu kuesioner. Hasil dari uji reliabilitas dan validitas menunjukkan bahwa seluruh pernyataan dalam setiap variabel reliabel dan valid.

Dalam uji asumsi klasik yang meliputi uji multikolonieritas, uji heteroskedastisitas dan uji normalitas menunjukkan bahwa dalam model regresi tidak ditemukan adanya korelasi antar variabel bebas dan tidak terjadi heteroskedastisitas serta memiliki distribusi normal.

Dari pembahasan yang telah diuraikan, maka dapat ditarik kesimpulan sebagai berikut:

1. Hasil pengujian hipotesis telah membuktikan terdapat pengaruh antara gaya kepemimpinan dengan kinerja karyawan. Pengujian membuktikan bahwa gaya kepemimpinan memiliki pengaruh positif terhadap kinerja karyawan. Dilihat dari perhitungan yang telah dilakukan diperoleh nilai koefisien sebesar 0,983 dan nilai $t$ hitung sebesar 11,323 dengan taraf signifikansi hasil sebesar 0,003 tersebut lebih 
kecil dari 0,05 , yang berarti bahwa hipotesis dalam penelitian ini menerima $\mathrm{Ha}$ dan menolak Ho.

2. Hasil pengujian hipotesis telah membuktikan terdapat pengaruh antara motivasi dengan kinerja karyawan. Pengujian membuktikan bahwa motivasi memiliki pengaruh positif terhadap kinerja karyawan. Dilihat dari perhitungan yang telah dilakukan diperoleh nilai koefisien sebesar 0,276 dan nilai t hitung sebesar 2,367 dengan nilai signifikansi sebesar 0,004 tersebut lebih kecil dari 0,05 dengan demikian Ha diterima dan Ho ditolak.

3. Hasil pengujian hipotesis telah membuktikan terdapat pengaruh antara disiplin kerja dengan kinerja karyawan. Pengujian membuktikan bahwa disiplin kerja memiliki pengaruh positif terhadap kinerja karyawan. Dilihat dari perhitungan yang telah dilakukan diperoleh nilai koefisien sebesar 0,257 dan nilai t hitung 3,479 dengan taraf signifikansi hitung sebesar 0,001 tersebut lebih kecil dari 0,05, yang berarti bahwa hipotesis dalam penelitian ini menolak Ho dan menerima $\mathrm{Ha}$.

4. Gaya kepemimpinan memiliki pengaruh yang paling kuat terhadap kinerja karyawan Yayasan Marvin.

\section{DAFTAR PUSTAKA}

Algifari. 2000. Analisis: Teori dan Kasus Solusi. BPFE. Yogyakarta.

Armstrong, Michael. 1994. Manajemen Sumber Daya Manusia: A Handbook Of Human Resource Management. PT Elex Media Komputindo. Jakarta.

Crimson, Sitanggang, 2005, Analisis Pengaruh Prilaku Pemimpin Terhadap Kinerja Pegawai Pada Sekretariat Kotamadya Jak-Bar. Skripsi, UNDIP Semarang.

Dale, Robert. D. 1992. Pelayan Sebagai Pemimpin. Gandum Mas. Malang.

Ghozali, Imam. 2005. Aplikasi Analisis Multivariate dengan Program SPSS. Semarang: BP Universitas Diponegoro. Semarang.

Handoko, T. Hani. 2003. Manajemen Edisi 2. BPFE. Yogyakarta.

Hasibuan, Malayu. 2004. Manajemen Sumber Daya Manusia. PT Bumi Aksara. Jakarta.

Malthis, R.L dan Jackson. 2001. Manajemen Sumber Daya Manusia. Salemba Empat. Jakarta.

Robbins, Stephen. P. 2006. Perilaku organisasi. Edisi Bahasa Indonesia. PT Indeks Kelompok GRAMEDIA. Jakarta.

Robbins, Stephen. P. dan Mary Coulter. 2005. Manajemen. PT INDEKS Kelompok Gramedia. Jakarta. 
Rivai, Veithzal. 2004. Manajemen Sumber Daya Manusia Untuk Perusahaan. PT RAJAGRAFINDO PERSADA. Jakarta

Rivai, Veithzal dan Basri. 2005. Performance Appraisal: Sistem Yang Tepat Untuk Menilai Kinerja Pendidik Dan Meningkatkan Daya Saing Perusahaan. PT RAJAGRAFINDO PERSADA. Jakarta.

Sekaran, Uma. 2006. Research Methode For Business: Metodologi Penelitian Untuk bisnis. Salemba Empat. Jakarta.

Siagian, Sondong. P. 2002. Kiat Meningkatkan Produktivitas Kerja. PT Rineka Cipta. Jakarta.

Simamora, Henry. 1997. Manajemen Sumber Daya Manusia. STIE YKPN. Yogyakarta.

Stoner, James. AF Dan R. Edward Freeman dan Daniel R. Gilbert. 1996. Manajemen. PT Prenhallindo. Jakarta.

Supranto, J. 2001. Statistik: Teori dan Aplikasi. Edisi keenam. Erlangga. Jakarta.

Tika, P. 2006. Budaya Organisasi Dan Peningkatan Kinerja Perusahaan. PT Bumi Aksara. Jakarta. 